UDC: 811.111:(057.87+075.8) https://doi.org/10.22190/JTESAP1903293V

\title{
MAKING THE MOST OF EXPERIENCE: FROM SYLLABUS TO TEXTBOOK DESIGN
}

\author{
Ljiljana Vukićević Đorđević \\ Faculty of Science, University of Kragujevac, Serbia \\ E-Mail: ljvukicevic@kg.ac.rs
}

\begin{abstract}
A well-crafted ESP syllabus fosters learning by bridging the gap between foreign language learning and the field of profession. Besides, ESP syllabi should promote a specific genre and content-based tasks established on and integrated with functional grammar and lexicon. In our classroom, we have adopted the situation-based learning approach and context-based vocabulary learning. Experimental science with English-based instruction offers the first-hand experience through observation inside laboratories to our students of biology, chemistry, and environmental science. Building up students' language competence is vocabulary-based and thus special attention is paid to word chunks and wordlists. Although often regarded as a 'service activity', ESP is also a medium between academic and popular genres. Teaching a foreign language, especially English as the lingua franca of our age, is not just a stultifying practice of teaching a thoughtful discipline but providing students with valuable vocational knowledge.
\end{abstract}

Key words: textbook design, syllabus, genre, chunks, wordlists

\section{INTRODUCTION}

ESP course development and syllabus design have received a lot of substantial, assiduous attention in recent times. However, education authorities appear to leave ESP instructors dealing with this important issue on their own. Thus, the absence of general statements about language learning that is supposed to be outlined by the curriculum may be given either a warm embrace or the cold shoulder at the same time. This is so since the former is allowed by the complete freedom of ESP practitioners in creating the syllabus and the latter results from the lack of availability of a general framework which encompasses both methods and objectives and provides a sense of direction for knowledge management.

There are various approaches to syllabus design. Essentially, major decisions are to be made about the "units" of classroom activity and the "sequence" in which they are to be performed (Robinson, 2009). In this regard, the authors proposed various types of syllabi focusing on grammatical elements, functions, situations, specific abilities, content or subject matter, and purposeful tasks. The role of the teacher is to participate in designing a syllabus which is of sound theoretical background and useful in practice as well. This implies not only a syllabus negotiated by teachers and their students (Rahimpour, 2010), but also the participation of professionals with specific expertise.

Submitted September $25^{\text {th }}, 2019$, accepted for publication October $9^{\text {th }}, 2019$

(C) 2019 by University of Niš, Serbia | Creative Commons License: CC BY-NC-ND 


\section{ENGLISH AND PROFESSIONAL FIELDS}

The role of teachers as ESP course developers is adumbrated by their students' needs and, as such, they face up to great responsibility for direction, methods, and resources they have provided and employed in the classroom. A well-crafted ESP syllabus fosters learning by bridging the gap between foreign language learning and the field of profession which means that English language and major field are expected to be successfully integrated. However, it is not an easy task but a challenging one. Students' previous learning experience and teachers' expectations have much to do with present situation analysis and target situation analysis (Flowerdew, 2013) implying lacks and needs and establishing the importance of both the process of learning and its goals.

Also, from the very beginning, ESP course designers have to decide on the content included in the course. If, as suggested (Basturkmen, 2010), the focus is on teaching the most common academic words and a register, then a generic set of skills in a particular field, e.g. informatics / chemistry / biology, is a chosen foundation for a general ESP course syllabus. On the other hand, a narrower approach assumes that ESP teachers and their students deal with more specific needs focussing on content and skills in sub-fields such as programming, web design, game development (informatics) / biochemistry, environmental protection, chemical engineering (chemistry) / botany, microbiology, zoology (biology), etc.

Since ESP courses are rarely tailored to suit the students of specific sub-fields of study, the analysis of students needs ought to commence with the analysis of their prospective job descriptions and performance standards, at least the entry-level ones. Taking into account that staying up to speed with rapid technological change requires a new mindset, skill development, and gaining experience and extensive expertise have become inevitable to move on or up, regardless of employers and labour market. Transferring this into classroom practice, there is a possibly daunting task ahead for ESP practitioners which means that special attention is to be confined to comprehensive syllabus design.

The concept of fully functioning professionals and their embedment within a social context assumes both professional knowledge and verbal skills. Thus, ESP syllabi should promote a specific genre and content-based tasks established on and integrated with functional grammar and lexicon. What should be emphasised is that ESP instructors should enable the connection of students' high-school knowledge of English with the specific use of structures and vocabulary in their professional field providing them membership in a discourse community.

Since content accuracy is the matter of utmost importance, ESP teachers are expected to work with discipline specialists to compensate for their incomplete content knowledge. Also, students themselves become informants and facilitate their ESP teachers' efforts. Due to the lack of textbooks in the field of English for Science, above all, for biology, chemistry and environmental science, ESP practitioners are coerced to write textbook themselves. Apart from a plethora of ESP textbooks on business administration, IT, finance, tourism and technology, scant attention has been paid to science which is largely dictated by labour market considerations. Here comes a new challenge!

\section{SitUATION-BASED LEARNING AND FIRST-HAND EXPERIENCE}

The very foundational cornerstone of our chemistry and biology/environmental science textbook was the content. Being an outsider in the professional field, we needed a helping 
hand from the insiders. The organisation of the textbook purposefully encompasses perspectives across the sub-disciplines and a so-called itemized list covering the basic terms (periodic table, chemical bonds, laboratory equipment, taxonomy, chlorophyll, etc.), major topics (history of chemistry, chemical reactions, origin of life, photosynthesis, environmental pollution, etc.), content-related language exercises and glossary.

We enjoyed not much freedom in making the list of basic terms despite the lack of an agreed set of such fundamental words. However, the fields of chemistry and biology cover a variety of topics considered essential, out of which we picked up some of the representative ones as standard for the genre. The main idea was to identify some themes that would be both attractive to students and based on fundamental disciplinary content. Having adopted the situation-based learning approach and context-based vocabulary learning, we endeavour to combine basic language skills. Whenever possible, students are supposed to be directly engaged in reading, speaking, listening and writing.

Particular attention in ESP teaching should be paid to vocabulary, especially to the pronunciation of words that exist in students' mother tongue as the same or similar words, such as the following:

chemistry (kemistri) - Serbian: hemija;

hydrogen (hardrədzən) - Serbian: hidrogen, vodonik;

valence (verləns) - Serbian: valenca;

mitochondrion (, martəu' kpndriən) - Serbian: mitohondrija;

ribosome ('raibə, səom) - Serbian: ribozom

Also, most of the speciality words in science encountered in the textbook come from ancient Greek and Latin languages. Such original/transliteration pairs in both singular and plural forms should also be presented since students are believed to come up with them during their university education and further professional development. Here are some examples:

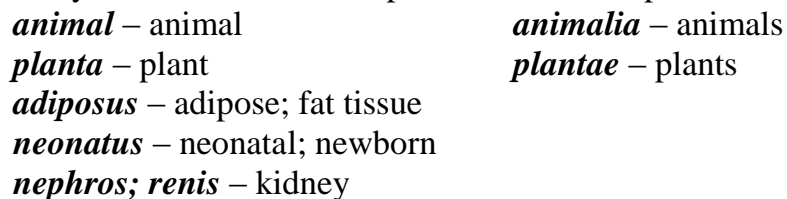

Using podcasts and other recordings in the ESP classroom may also prove highly beneficial for students, particularly for enhancing their listening skill and receiving messages effectively. Performing experiments inside chemistry or biology laboratories and combining it with instructions provided in English leads to more fruitful teaching and learning environments. Of course, mediated learning and novel communication technologies along with the productive use of the Internet should be encouraged in ESP classrooms. Since listening comprehension material and interesting authentic listening material help vocabulary retention (Salem, 2017), teachers' understanding of learners' learning styles may be supported by using infinitely many sources such as podcasts mentioned earlier (www.thenakedscientists. com, www.chemistryworld.com, www.nature.com, https://player.fm/podcasts, etc.) and laboratory manuals in the form of video clips on YouTube (Science Lab Manual Classes, BBC Earth Lab, Biology Practicals and Revision Biology Tutor, etc.).

While inside the laboratory, students of science have to read labels and interpret the information provided about each substance. Thus, practical issues appear to be confronted by freshman students from the outset of their university education. Based on the Globally Harmonised System (GHS) for classification and labelling, the students of science meet an internationally agreed system for hazard classification of chemical products and for 
communication of those hazards, such as acute toxicity, carcinogenicity, irritation or corrosivity, mutagenicity, reproductive toxicity, sensitisation, and chronic or repeat dose toxicity. These harmonised labelling elements are used as pictogram symbols, signal words, and hazard statements. But, before entering the laboratory, students are to meet, demonstrate, and assess safe laboratory practices. Since different styles of laboratory instruction have been utilized over time, students will benefit most from the combination of traditional explanation, inquiry, and problem-based situations.

Experimental science offers first-hand experience through observation and, when innumerable observations are placed into a rational order, a general framework for the theory is established. Generally, it is a story, and, combining historical evolution and current practice in science, students learn both the facts and how to communicate their results when performing experiments. They take part in an experiment on both observing demonstrators' performance and note-taking and combine their notes with ESP teacher presentations attempting to synthesise information in their own words. Dialogue, role-play, miming and drama, authentic scenario, and other oral techniques may be both beneficial and amusing.

\section{FROM WORD TO WORD CHUNKS}

Gradually but seemingly steadily, the English language is becoming a medium of teaching subjects other than English, especially with outbound student mobility and CLIL (Content and Language Integrated Learning) emerged from teaching innovations in Finland over 20 years ago. Particular experiences gained so far emphasise not only the subject-specific vocabulary, but also chunks as functional expressions and types of collocations. To help students remember these expressions, it is useful to repeat them in different ways - using the English textbook and extracts from adapted scientific papers and science textbooks in English. If necessary, educators have to resort to translation into the mother tongue to enhance both productive and receptive skills (Duff, 1989).

To become a fully-functioning professional, students are to be properly exposed to situations they ought to deal with in the future. Task-based learning can be fruitful when writing, e.g. when assigned to prepare the presentation, students are encouraged to generate extended chunks of words enabling themselves to acquire collocations through the genre's discourse. Let us pay attention to the word species:

Task 1: Expand the chunk 'identify plant species' by forming collocations.

Identify related plant species

Identify closely/distantly related plant species

Identify closely/distantly related flowering plant species

Identify closely/distantly related wild flowering plant species

Identify five closely/distantly related wild flowering plant species

Identify five European closely/distantly related wild flowering plant species

Task 2: Expand the chunk 'species in Europe'.

Species occurring in Europe

Species occurring in Southern Europe

Several species occurring in Southern Europe

Several algal species occurring in Southern Europe

Several rare algal species occurring in Southern Europe

Several rare algal species naturally occurring in Southern Europe 
Besides, technical vocabulary or specialised words used in particular scientific fields are not necessarily highly technical although a large number of the new words encountered in the textbooks in use have derived from Latin and Greek origins. For instance, bug and mouse are both frequent words in biology but distinct meanings of these words have developed in IT. Also, the syntagmatic structure physical property (characteristic) used in the discourse of chemistry, substantially differs from the physical property (assets) in legislation. On the other hand, so-called 'lexical bundles' - three or more words repeated unchanged in a particular corpus - which often occur in the classroom also deserve further attention. Common patterns can be identified in different ESP contents and scientific disciplines regardless of whether they discuss the content (on the basis of, it is possible to, the relationship between the), express attitudes (it is possible to, it is important to, it is necessary to), or organize discourse (on the other hand, at the same time, the end of the).

Vocabulary in science and IT does not differ much from country to country, thus ESP educators in these professional fields have less trouble if compared to colleagues dealing with law and accountancy. So, it is easier to connect new vocabulary with already known and to focus on target situations when designing the syllabus and educational material. Laboratory experiment, chemical equations used for process description, and elaboration of industrial-scale production are just some key pillars in the structure of chemistry/English syllabus. Phases of product development for particular client, customer care/help and discussing product specifications are mentioned here as examples related to IT/English, and the students of biology/ecology can begin with the simple elaboration of taking care of home plants, and later extend their knowledge with discussion related to the environmental legislation and conferences (Kyoto, Copenhagen) and local activism (planting trees) that will enable them communicate with students worldwide and contribute to resolving issues of outstanding global importance, e.g. Russia and Amazon forest fires this summer.

Two- and three-hour weekly periods spreading over a semester-/year-long basis, as most often in Serbia, seem to be insufficient to acquire the knowledge of basic concepts, let alone the updated functional knowledge. Since the same textbooks are supposed to be used throughout the period of accreditation and become increasingly obsolete, especially in IT courses, ESP educators have to review and refresh their accompanying materials with the available Internet sources (Nobel Prize-winning discoveries, global environmental issues, feasibility studies, Microsoft protocols, Huawei press releases, up-to-date achievement reports, etc.). Keeping students up-to-date with the development in particular fields, even using popular science magazine texts instead of scientific journal articles, appeared to be the best method to provide both their access to the discourse community and keep them interested at all.

While textbooks generally use abstract nominalizations as subjects of processes (Parkinson, 2013) and have already been accepted by the scientific research community, in our opinion, the genre should not be explicitly taught. To support the assumption, let us give an example of biology students being 'immersed' in the disciplinary culture and thus learning of genre features unintentionally when dealing with environmental degradation, sustainable development and the tools to slow down or turn about environmental damage. They are not researchers deeply involved in the field and phenomena, but only a part of the learning society confronted with the problem to find the solution for. Their down-to-earth reports make them feel closer to scientific research and connect them to the scientific circles.

Nominalizations in science and IT discourse enable compression of information and more abstract generalisation which is often untranslatable into mother tongue following 
the patterning of the original (e.g. GUI-graphical user interface: how a user interacts with a computer using text and images; $P 2 P$ - peer-to-peer: a network model in which computers or hardware devices exchange files; split-brain patient: the patient subjected to surgical separation of the hemispheres of the brain; tumour suppressor protein: protein acting as a tumour suppressor; tear gas: gas that causes severe irritation to the eyes; combustion tube: a tube of heat-resistant glass, silica, or ceramic, in which a substance can be reduced), sometimes slightly clumsily literally translated (e.g. rare earth metals: metali retke zemlje) or, in particular cases, even horrifying (designer baby: a baby whose genes have been chosen by its parents and doctors so that it has particular characteristics).

Discipline-specific writing in a genre-based approach, in spite of already established framework of instructions, is not simply mastering a set of rules to adhere to. Going stepby-step enables students to develop their listening and reading skills paving the way for writing and speaking that follow. Designing reports and presentations is often troublesome if students do not have enough successful practice at writing the same even in their mother tongue or if they are not familiar with problem-based learning at all. ESP instructors are expected to draw students' attention to the nominal expression of meaning instead of 'clausal packaging of meaning' (Halliday, 1993) as used in written scientific text:

Breakdown voltage is lower because the electric field is changed. (clausal packaging)

The changing electric field causes a lower breakdown voltage. (nominal packaging)

\section{FROM WORD TO WORDLISTS}

Of course, the vocabulary of science differs from everyday vocabulary. Wordlists such as the General Service List (a list of words chosen in 1953 by Michael West because they were thought to be of greatest 'general' use to learners of English), the New General Service List (a major update the General Service List of core vocabulary for second language learners made in 2013), and the Academic Word List (a list of words which appear with high frequency in English-language academic texts compiled by Coxhead in 2000) are believed to be fairly helpful to students of various scientific disciplines.

Since general academic wordlists have been questioned regarding their usefulness and core academic vocabulary (Durant, 2016), a resulting trend appeared toward disciplinespecific wordlists. In 2015, for instance, Liu and Han derived a word list from corpora of environmental science as a field-specific word list that better reflects specialized features.

However, being familiar with words in the GSL which covers around $80 \%$ of words in general corpus and words in the AWL covering $10 \%$ of academic corpus which provides knowledge of roughly $90 \%$ in academic texts (the AWL: www.eapfoundation.com) is not enough. Disciplinary contexts and raising awareness of collocations as chunks are always helpful along with visual elements - graphs, diagrams, flowcharts, family trees, timelines, etc. A list of academic two-word bigrams, most often composed of lexical words combined with function words developed by Durrant in 2009 was, to some extent, disappointing for teachers searching for the more 'concept-carrying' phrases. Nevertheless, technical words or words displaying obvious discipline specificity are often combined with words which exhibit less straightforward discipline specificity which contributes to acquiring specialized language patterns of a particular subject.

Generally, discipline-based literacy is established firstly on words - general, academic, discipline-specific and law-frequency ones - and secondly on the general grammar of English. 
Developing phrase list provides a particular bridge between 'elements' and 'compounds' assuming the above-mentioned Academic Word List and the Academic Formulas List derived by Simpson-Vlach and Ellis in 2010 and focused on academic lexical bundles. The first steps are usually hesitant but considerable as well.

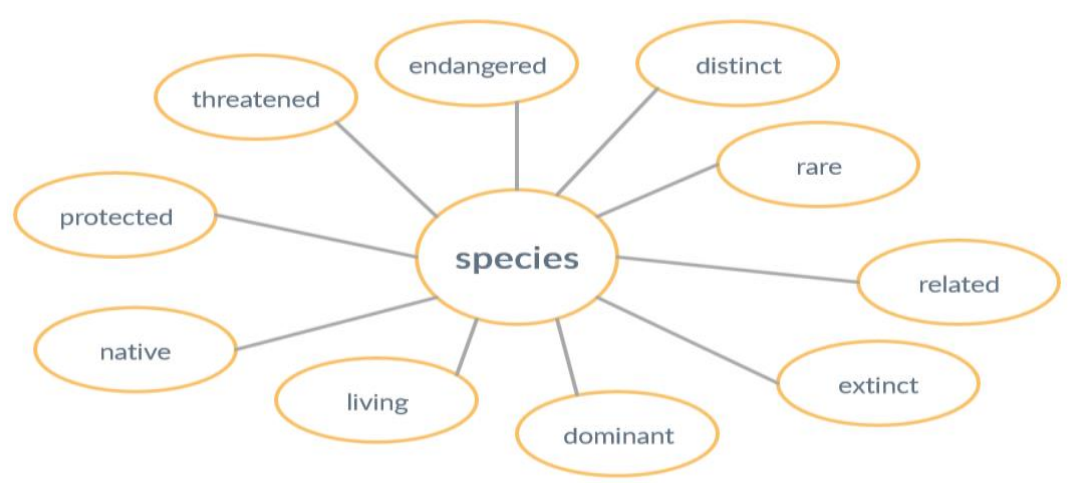

Fig. 1 Species spidergram

Using word lists and word families including a headword and inflected and derived forms suffers from a major drawback, especially when it comes to IT, since new words are coined and traditional use is modified on a daily basis. Thus, word lists and word families require to be updated although the GSL is still reliable in its coverage figures over different corpora and has yet to be replaced (Coxhead, 2013).

In designing their course materials and textbooks, ESP practitioners can prepare the tables with the most frequent phrases related to their particular disciplines including various combinations of words within phrases. Here is just an example of such a preliminary activity with the most frequent word phrases in the textbooks in use.

Table 1 Most frequent word phrases

\begin{tabular}{|c|c|c|c|}
\hline & Biology & Chemistry & IT \\
\hline Noun-noun & $\begin{array}{l}\text { amino acid } \\
\text { cell wall } \\
\text { animal species }\end{array}$ & $\begin{array}{l}\text { formula mass } \\
\text { oxidation state } \\
\text { carbon dioxide }\end{array}$ & $\begin{array}{l}\text { software licence } \\
\text { resident virus } \\
\text { storage device }\end{array}$ \\
\hline Adjective-noun & $\begin{array}{l}\text { fatty acid } \\
\text { human being } \\
\text { abiotic factor }\end{array}$ & $\begin{array}{l}\text { gaseous state } \\
\text { chemical change } \\
\text { positive charge } \\
\end{array}$ & $\begin{array}{l}\text { private cloud } \\
\text { real time } \\
\text { animated GIF } \\
\end{array}$ \\
\hline Noun-verb & $\begin{array}{l}\text { cells divide } \\
\text { blood flows } \\
\text { phylum called } \\
\end{array}$ & $\begin{array}{l}\text { reaction causes } \\
\text { compound contains } \\
\text { effect observed }\end{array}$ & $\begin{array}{l}\text { website offers } \\
\text { data processed } \\
\text { code identifies } \\
\end{array}$ \\
\hline Verb-noun & $\begin{array}{l}\text { produce hormone } \\
\text { digest food } \\
\text { produce offspring }\end{array}$ & $\begin{array}{l}\text { share electrons } \\
\text { perform experiment } \\
\text { add water }\end{array}$ & $\begin{array}{l}\text { get access } \\
\text { change layout } \\
\text { open file }\end{array}$ \\
\hline Verb-adverb & $\begin{array}{l}\text { break down } \\
\text { made up } \\
\text { explain how }\end{array}$ & $\begin{array}{l}\text { carry out } \\
\text { slow down } \\
\text { show how }\end{array}$ & $\begin{array}{l}\text { write down } \\
\text { set up } \\
\text { go back }\end{array}$ \\
\hline
\end{tabular}


Such two-word lexical combinations as listed above could greatly enhance the teaching of disciplinary literacy and, over years, it appears that more attention has been given to them in course materials and textbooks development. Collocation dictionaries may also strengthen full support for both ESP teachers and their students.

\section{ACADEMIC AND POPULAR GENRES}

ESP is often regarded as 'service activity' (Hyland, 2002) with exercises designed to fix-up students' problems. Since a large number of freshmen usually enter university education with a marked deficit of literacy skills, let alone fluency, ESP practitioners must combine general English with ESP for the more considerable achievement of their students and provide an encouraging, inspiring, and positive atmosphere in the classroom. Regardless of discipline, purpose, or profession, generic skills and language forms are the same for all. If presented visually and in terms of Information Technology, the process of acquiring and developing English language skills is as follows:

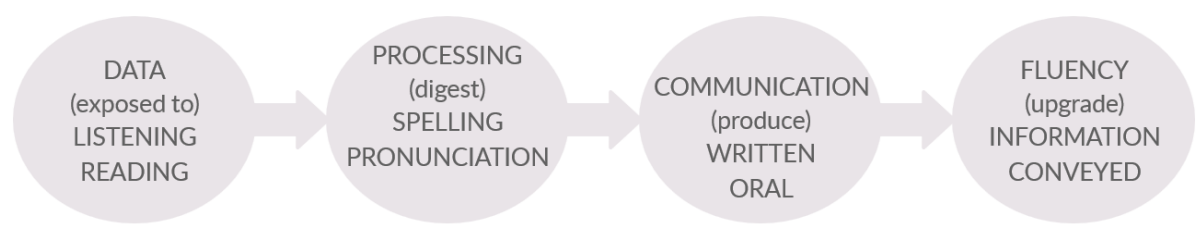

Fig. 2 Acquiring and developing the English language skills

What can be seen as a major problem inside an ESP classroom is establishing enough common ground among students since classes are rather heterogeneous. To make science more accessible to students, ESP teachers can use materials that help to bring science closer to students and resort to popular science articles. Generally, three types of reading materials are intended for different groups of readers: research papers for the research community, textbooks for students, and popular science articles for the general public. The last-mentioned can be undoubtedly useful inside ESP classrooms, especially for its population-based power relations between the reader/student and the writer which appear to be equal (Parkinson, 2004), as opposed to a learning-based textbook with the reader/student less powerful than its writer, and a science-based research paper with the reader more powerful in comparison to its writer. Thus, popular science articles simply prepare students who are without enough experience and knowledge by immersing them in an intensive learning environment.

Since popular science texts report on new findings, they follow current trends and are not threatened to become obsolete as textbooks often are, especially in Information Technology and other scientific disciplines characterised by accelerated development. Thus, popular texts have been made valuable additional material inside ESP classrooms and furthermore, they whip up students' enthusiasm for learning. Since they are often accompanied by illustrations, cartoons, and graphs, they make scientific discipline less abstract and more learnable.

Interestingly enough, what sometimes represented information retrieved from popular science texts is often later embedded in the textbooks. Let us mention the research on 
nuclear transfer performed at the Roslin Institute in Scotland that ultimately resulted in the creation of Dolly in 1996, the first animal ever cloned from an adult cell. Pro and contra arguments have been weighed ever since and the information related to the achievement of Scottish researchers, after research papers and popular science articles, became a topic in the textbook.

Likewise, information related to GMO and disseminated through the mass media and research papers can represent an example of an interesting students' presentation or seminar paper prepared at this very moment but also a well-discussed topic for a future textbook based on bold but testable hypotheses that were examined and either accepted or rejected. In the meantime, the 'more mature' information should be gathered, checked, and published.

University students should deal with both popular and academic sources of information since they deal with 'social construction of scientific knowledge' and have to be able to 'translate' between genres. Beginning with a simple lab experiment, students can describe the experimental methods, procedures, equipment, and results using a particular story of scientific discovery, key findings, and discoveries. Furthermore, they can also pay attention to important trends in research at higher levels of their study and even highlight unforeseen results. From an ESP point of view, students of science should bear in mind disciplinary conventions as well as English grammar rules and content organisational features. Regardless of their future field of work, while at university, students of science should benefit from explicit instruction, discussion, practice, feedback, and time to develop the analytical skills needed in the field (Stoller, 2013).

\section{CONCLUSION}

To conclude, content- and theme-based language courses for biology, chemistry and IT students represent the first choice of both ESP practitioners and literature that has mushroomed in recent decades and has become a 'default setting'. Learners' previously acquired English language proficiency is equally important as their discipline-specific background. Thus, achieving and development of scientific literacy inevitably entail practical mastery of the English language.

Although no consensus exists about the definition of scientific literacy, a professional of our times is seen as an individual with both vocational and English language skills. It has not ever changed since prudent and knowledgeable men over history were also supposed to be familiar with and competent in languages - Greek and Latin. From this point of view, teaching a foreign language, especially English as the lingua franca of our age, is not just a stultifying practice of teaching a thoughtful discipline but providing students with valuable vocational knowledge and practical experience to struggle for survival in times of globalisation insofar as survival is for the fittest. 


\section{REFERENCES}

Basturkmen, H., Developing Courses in English for Specific Purposes. Palgrave Macmillan, 2010

Coxhead, A., "Vocabulary and ESP" in The Handbook of English for Specific Purposes. (2013): 115-132

Duff, A. M., Translation. Oxford University Press, 1989

Durant, P., "To what extent is the Academic Vocabulary List relevant to university student writing" in English for Specific Purposes, 43 (2016): 49-61

Flowerdew, L., "Needs Analysis and Curriculum Development in ESP" in The Handbook of English for Specific Purposes. (2013): 325-346

Halliday, M., Kirkwood, A., "Some grammatical problems in scientific English" in Writing Science, edited by M. A. K. Halliday and J. R. Martin. (1993): 69-85

Hyland, K., "Specificity revisited: how far should we go now?", English for Specific Purposes, 21 (2002): 385-395

Parkinson, J., Adendorff, R., "The use of popular science articles in teaching scientific literacy”, English for Specific Purposes, 23 (2004): 379-396

Parkinson, J., "English for Science and Technology" in The Handbook of English for Specific Purposes. (2013): 162-180

Rahimpour, M., "Current trends on syllabus design in foreign language instruction". Procedia Social and Behavioral Sciences 2 (2010): 1660-1664

Robinson, P., "Syllabus Design" in The Handbook of Language Teaching. (2009): 289-305

Salem, A., "Engaging ESP Students with Brain-Based Learning for Improved Listening Skills, Vocabulary Retention and Motivation", English Language Teaching, 10:12 (2017): 182-195

Stoller, F. L. and Robinson, M. S., "Chemistry journal articles: An interdisciplinary approach to move analysis with pedagogical aims" in English for Specific Purposes, 32 (2013): 45-57

The Academic World list (AWL), accessed August 20, 2019, https://www.eapfoundation.com/vocab/academic/awllists 